International Journal of Social Science And Human Research

ISSN(print): 2644-0679, ISSN(online): 2644-0695

Volume 04 Issue 12 December 2021

DOI: $10.47191 / \mathrm{ijsshr} / \mathrm{v} 4-\mathrm{i} 12-69$, Impact factor-5.586

Page No: 3954-3958

\title{
Effects of REACT (Relating, Experiencing, Applying, Cooperating and Transferring) Learning Model Critical Thinking Skills and Creativity Skills of Millennial Students in High School
}

\author{
Wahyuni ${ }^{1}$, Abdul Razak ${ }^{2}$ \\ ${ }^{1,2}$ Master of Biology Education, Padang State University, Padang, Indonesia
}

\begin{abstract}
This research aims to find out the influence of react learning model on critical thinking skills and creativity skills of millennial high school students 6 Kerinci. This type of research is (quasi-expriment) research with the One Group Pretest-Posttest Design model. The study consisted of two classes: a control class and an experimental class. Before the learning process, the activity of reading the Qur'an and its translation related to student learning motivation. In the experimental class was given the treatment of react plus learning model (innovation, effectiveness of time and teacher as facilitator) and control classes using conventional learning models (lectures). The results showed (1) The value of critical thinking skills of students taught with the REACT model is higher than the critical thinking skills of students taught with conventional learning models in class X MIPA State High School 6 Kerinci. (2) Student learning creativity skills taught with react model are more effective than student learning creativity skills taught with conventional learning models in class X MIPA State High School 6 Kerinci.
\end{abstract}

KEYWORDS: REACT Learning Model, Critical Thinking Skills, Creativity Skills, Millenial Students

\section{INTRODUCTION}

The Industrial Revolution 4.0 had a profound influence on changes in all sectors of life (Putri \& Muzakki, 2019). The influence of the Industrial Revolution 4.0 is very important to the joints of life, one of which is on the world of education (Oktavian \& Aldya, 2020). Education at this time requires that students must be able to master technology and learning skills (Mulyadi dkk., 2020). Education is still one of the pillars that welcome progress in all scientific fields in the world. The challenges that must be faced by the world of education in the era of Revolution 4.0 can be seen from the way of thinking, how to learn, how to act students in order to develop various innovations and creativity in education (Nursyifa, 2019). Education in the era of revolution 4.0 is seen as the development of four great competencies of the 21st century, two of which are critical thinking skills and creativity (Lukum dkk., 2019).

Facing the era of revolution 4.0 in the 21 st century, education is needed that can shape the creative, innovative, and competitive generation (Rahman \& Nuryana, 2019). Some that must undergo adjustments are: Changing the way students look, changing the way they look at technology, getting used to collaboration and teamwork, reorienting the curriculum, reorienting assessments, using blended learning and others (Trisna, 2019). This era will induce an educational revolution into education 4.0 that demands fundamental changes in the learning process. In addition, education must also be immediately transformed into modern to ensure students have knowledge, learning skills and innovate.

This 21st century students are commonly referred to as millennials and must also have a strong character, so that they are not uprooted from their noble cultural roots (Sultoni dkk., 2020). Characteristics of the millennial generation are: 1) Millennials believe in User Generated content (UGC) rather than unidirectional information, 2) Millennials prefer mobile phones over TV, 3) Millennials must have social media, 4) Millennials do not like to read conventionally, 5) Millennials tend to be disloyal but work effectively, 6) Millennials tend to make transactions cashless, 7) Millennials know technology better than their parents, 8) Millennials utilize technology and information, 9) Millennials tend to be more lazy and consumptive and others (Hidayatullah dkk., 2018). This generation is practical, rather intelligent than wise, likes to lead because they are bolder, more impatient, more agile than their predecessors and look for new challenges and encouragement continuously. This generation is not afraid of continuous change and because the internet world this generation has a lot of information, but only to some extent (Bencsik et al., 2016). The latest changes in education emphasize being able to develop and improve learning that leads to problem solving, learning and reasoning skills (Pramudita dkk., 2021). 


\section{Effects of REACT (Relating, Experiencing, Applying, Cooperating and Transferring) Learning Model Critical Thinking Skills and Creativity Skills of Millennial Students in High School}

Teacher and Lecturer Law No.14 of 2005 Chapter I article I reports that teachers are reliable educators with the main task of educating, teaching, guiding, concentrating, training, assessing and evaluating students (Farhana dkk., 2021). This is a challenge that must be faced by both educational institutions and teachers to make students able to master the skills of the 21st century. Learning in the 21 st century demands a teacher who is able to perform, realize effective, systematic accurate and precise learning (Razak dkk., 2021). To achieve that target, relevant models and approaches are needed in the 21st century. A model is a comprehensive plan that integrates all resounsces and capabities that have a long-term goal of winning competence (Anggraeni, 2019).

The latest learning models can be used and adapted in the development of learning such as multiliteration-based, guidedbased inquiry learning models that are useful to increase the creative and critical thinking power of students through the mastery of literacy that varies (Julianda dkk., 2018). Then there is the REACT learning model which is a context learning model that is based on how students learn to gain understanding and how teachers teach to provide understanding (Dewi, 2015).

Based on the results of observations at Sma Negeri 6 Kerinci, it was found that before the learning process, the Teacher had not applied the process of reading the Qur'an and its translation related to student learning motivation, The Teacher only applied to read prayers before learning. Furthermore, in the learning process, teachers more often use the convention learning model (lecture) than other learning models that are more suitable for use in 21 st century education or for millennial students who can encourage students to think critically, In this case, teachers are less creative in developing new learning models, teachers tend to be the center of information conveying and students are less involved in the learning process. Thus causing the low understanding of students to the material taught, this has an impact on the learning outcomes of students who have not reached KKM, which can be seen from the average grade of Daily Repeat results of students of class X MIPA in biology protist material subjects, namely students X MIPA1: 67.00 X MIPA2 : 69.10 and X MIPA3 : 68.20 which shows student learning results are still below KMM.

In addition, from the results of the student's critical thinking questionnaire showed that the student's critical thinking skills were still low, where the percentage of critical thinking skills of students of class X MIPA as many as five indicators gave a simple explanation of $57.2 \%$, build basic skills $59.5 \%$, conclude $57.3 \%$, give further explanation $56.2 \%$, set strategies and tactics $60.1 \%$. From the results of these percentages showed that the critical thinking skills of students are more dominant category is quite good. As well as from the observations of students' learning, Less than $80 \%$ showed that students' creativity in the learning process is less effective and also biology subjects including materials that are difficult for students to understand, due to the large material and require understanding from students. Moreover, for 21st century education or for students born in generation Z, where students born in this generation are required to be able to think critically and be able to solve problems and students in generation $\mathrm{Z}$ also want everything that is fast-paced, lacks ambition to be successful and very quickly adapt to technology.

\section{METHOD}

\subsection{Type of research}

This research is a quasi-expriment experiment with the One Group Pretest-Posttest Design model. This study was conducted to see the comparison of gain scores, by giving pretest to the subject, then given treatment within a certain period of time, then done posttest (Lufri \& Ardi., 2017).

\subsection{Population and sample}

The research population is a student of State High School Class X 6 Kerinci school year 2021/2022. The research sample consisted of two classes: the experimental class and the control class. In the experimental class and control class is given a pretest then continued with the treatment.

\subsection{Research procedure}

This experimental procedure uses the following procedures and research steps: (1) Preparatory stages (Making observations to school, Conducting experimental class determination and control classes, Preparing learning devices). (2) Implementation stage (This research is conducted in two classes namely experimental classes and control classes). (3) Completion stage (Provide posttest and questionnaire to students, Draw conclusions).

\subsection{Research instruments}

Validity of tests and questionnaires, reliability of tests and questionnaires, test difficulty index and different power of tests.

\subsection{Data collection techniques}

Data collection techniques used, namely observation techniques, tests and questionnaires.

\subsection{Data analysis techniques}

Data analysis in this study uses, normality test, homogeneity test, hypothesis test (hypothesis testing uses one-way anova test using SPSS software version 24), and N-Gain test. 
Effects of REACT (Relating, Experiencing, Applying, Cooperating and Transferring) Learning Model Critical Thinking Skills and Creativity Skills of Millennial Students in High School

\section{RESULTS AND DISCUSSION}

Results

3.1 Critical Thinking Skills Taught Using REACT Learning Models Are More Effective Than Students' Critical Thinking Skills Taught With Conventional Learning Models

From the test results of critical thinking skills obtained test scores that are processed to answer the proposed hypothesis.

Table 1. Distribution of Test Scores Results of Critical Thinking Skills Of Experimental And Control Classroom Students

\begin{tabular}{l|ll}
\hline Test Scores & Frequency & \\
\cline { 2 - 3 } & Experimental Class & Control Class \\
\hline $51-60$ & 0 & 5 \\
$61-70$ & 3 & 14 \\
$71-80$ & 16 & 8 \\
$81-90$ & 9 & 3 \\
$91-100$ & 2 & 0 \\
\hline
\end{tabular}

From Table 1 it is seen that students in the experimental class obtained grades at high intervals of $91-100$ as many as 2 people and at low intervals of 61 - 70 as many as 3 people. While in the control class obtained a score at intervals of $81-90$ as many as 3 people and a score at a low interval of 51 - 60 as many as 5 people. Based on KKM for Biology subjects at Sma Negeri 6 Kerinci which is 75 , then students in the experimental class test scores test results of critical thinking skills of the average student has reached KKM. While in the test score test class the results of critical thinking skills of the average student still did not reach KKM.

\subsection{Students' Learning Creativity Skills Using The REACT Learning Model Are More Effective Than Students' Learning} Creativity Skills With Conventional Learning Models.

In this study, indicators of students' learning creativity skills in sample classes observed include Flexibility, Originality, Elaboration, Fleuncy.

In the experimental class where learning is carried out with the REACT plus learning model, before the learning process students do activities to read the Qur'an and its translation related to learning motivation, emphasize the effectiveness of students while teachers are only facilitators in the learning process, where there are five stages in this REACT learning model, namely Relating that is learning begins by associating new concepts to be learned with the experience or context of student life, experiencing at this stage students build by associating new concepts learned based on experiences that he has gained before, Applying this applying stage will measure the student's understanding of the extent to which students understand a concept and how students apply the concept, Cooperating can share knowledge with each other at this stage students are given the opportunity to put their ideas forward in presentations quation and answer, and Trasfering encourages students to learn to use the knowledge that has been learned in the classroom based on understanding. This leads to students more creativity during learning in the experimental class than in the control class.

Table 2. Recapitulation of Students' Learning Creativity Skills Results

\begin{tabular}{lll}
\hline Students' Learning Creativity Skills & Experiment Class & Control Class \\
\hline Fleksibelitas & 826 & 807 \\
Originalitas & 734 & 709 \\
Elaborasi & 534 & 510 \\
Fleuncy & 1048 & 997 \\
\hline
\end{tabular}

\section{Test Analysis Requirements}

\section{Test of normality}

From the results of the normality test test it appears that the sig value $>0.05$ (a real level that has been set) for all tests, meaning normal distributed data.

\section{Homogeneity test}

From the results of homogeneity tests using Spss it is seen that the sig value of $>0.05$ means that the data varies homogeneously.

3. One-Way Anava Test

H0 : REACT plus Learning Model (innovation, effectiveness of time and teachers as facilitators) is not effective against Critical Thinking Skills and Creativity of Learning Millennial Students in State High School 6 Kerinci. 
Effects of REACT (Relating, Experiencing, Applying, Cooperating and Transferring) Learning Model Critical Thinking Skills and Creativity Skills of Millennial Students in High School

H1 : REACT plus Learning Model (innovation, effectiveness of time and teachers as facilitators) effective against Critical Thinking Skills and Creativity learning Millennial Students in State High School 6 Kerinci

Table 3. Results of Hypothesis Testing Calculations

\begin{tabular}{llllll}
\hline ANOVA & & & & & \\
\hline Kelas & & & & & \\
\hline & Sum of Squares & df & Mean Square & F & Sig. \\
\hline $\begin{array}{l}\text { Between } \\
\text { Groups }\end{array}$ & 183706,667 & 1 & 183706,667 & 3458,663 &, 000 \\
$\begin{array}{l}\text { Within } \\
\text { Groups }\end{array}$ & 3080,667 & 58 & 53,115 & & \\
Total & 186787,333 & 59 & & & \\
\hline
\end{tabular}

From table 3 it appears that the sig value $<0.05$ or means $H_{0}$ rejected and $H_{1}$ accepted. This means that students' critical thinking skills and learning creativity skills with react plus learning models are effective compared to critical thinking skills and student learning creativity skills with conventional learning models.

4. N-Gain test

The learning model is said to be effective if students' critical thinking skills experience improvements characterized by the results of analysis using N-Gain.

$$
\begin{aligned}
\text { N-Gain } & =\frac{\text { Posttest Value }- \text { Pretest Value }}{\text { ideal score }(95)-\text { Pretest Value }} \\
& =\frac{81-51,167}{95-51,167} \\
& =0,68(\text { Keep })
\end{aligned}
$$

\section{Discussion}

\subsection{Critical Thinking Skills Taught Using REACT Learning Models Are More Effective Than Students' Critical Thinking Skills Taught With Conventional Learning Models}

Judging from the results of students' critical thinking skills, the REACT learning model provides enhanced students' critical thinking skills compared to conventional learning models. This is seen from the average score of the results of critical thinking skills of students in the experimental class higher than the control class. The results showed that the REACT learning model was more effective against critical thinking skills than students' critical thinking skills in control classes with conventional learning. The results of higher critical thinking skills obtained by students in experimental classes are due to the REACT learning model that can make students more active and easy to understand the material studied.

This is in accordance with the opinions expressed by Junedi and Ayu (2018), that by using the REACT learning model can make students more active and easy to understand the material studied. This can be seen from the concept of react learning model, the role of teachers only in relating activities where students are directed to understand the material being studied by associating it with experience or understanding, furthermore, the learning stages are carried out by students, both independently and in cooperation, so that students can understand the subject matter they learn.

\subsection{Students' Learning Creativity Skills Using The REACT Learning Model Are More Effective Than Students' Learning Creativity Skills With Conventional Learning Models.}

Creativity skills are a very important principle in the learning process. Because learning is an act, students do creativity. Students who have more creativity in learning will encourage improvement in their learning outcomes or critical thinking skills. The ability of students to think critically can be seen by using the REACT learning model in the learning process. Students who have creativity will be able to work in group work, both discussions in groups and percentages in groups.

Hypothesis testing shows that students' learning creativity skills in experimental classes are higher than those of control class learning creativity. The REACT learning model can change learning where students become more active. This is in accordance with the opinion Hasanah dkk., (2019) that learning with the REACT model is effectively reviewed from problem-solving skills with a significant average of over 70. In groups each student has a responsibility to understand the results of his group work, thus generating creativity in the learning process. 


\section{Effects of REACT (Relating, Experiencing, Applying, Cooperating and Transferring) Learning Model Critical Thinking Skills and Creativity Skills of Millennial Students in High School}

\section{CONCLUSIONS}

Based on the results of the previously outlined research can be concluded as follows:

1. The value of students' critical thinking skills taught with the REACT model is higher than the critical thinking skills of students taught with conventional learning models in class X MIPA State High School 6 Kerinci.

2. Student learning creativity skills taught with react model are more effective than student learning creativity skills taught with conventional learning models in class X MIPA State High School 6 Kerinci..

\section{REFERENCES}

1) Anggraeni, N. E. (2019). Strategi Pembelajaran Dengan Model Pendekatan Pada Peserta Didik Agar Tercapainya Tujuan Pendidikan Di Era Globalisasi. ScienceEdu, April, 72. https://doi.org/10.19184/se.v2i1.11796

2) Dewi, F. (2015). Proyek Buku Digital: Upaya Peningkatan Keterampilan Abad 21 Calon Guru Sekolah Dasar Melalui Model Pembelajaran Berbasis Proyek. Encyclopedia of Psychology, Vol. 7., 220-224. https://doi.org/10.1037/10522-098

3) Farhana, S., Safitri, A., \& Tangerang, U. M. (2021). Strategi Guru Dalam Meningkatkan Kwalitas Mengajar Di Masa Pandemi Covid-19. 1(3), 313-320.

4) Hasanah, N., Buchori, A., Prasetyowati, D., \& Nursyahidah, F. (2019). Efektivitas model pembelajaran Relating, Experiencing, Applying, Cooperating, Transferring (REACT) dan reciprocal teaching berbantuan game edukasi. Pythagoras: Jurnal Pendidikan Matematika, 14(1), 92-101. https://doi.org/10.21831/pg.v14i1.17157

5) Julianda, Widiati, U., \& Djatmika, E. T. (2018). Pengaruh Strategi Pembelajaran Inkuiri Berbasis Keterampilan Multiliterasi terhadap Kemampuan Berpikir Kritis Siswa. Jurnal Pendidikan: Teori, Penelitian, Dan Pengembangan, $3(4), 460-467$.

6) Junedi, B., \& Ayu, D. M. (2018). Penerapan Strategi Relating, Exsperiencing, Applying, Cooperating and Transfering (React) Terhadap Pemahaman Konsep Matematika Siswa Kelas Viii. MES: Journal of Mathematics Education and Science, 3(2), 125-132. https://doi.org/10.30743/mes.v3i2.502

7) Lufri \& Ardi. (2017). Penelitian Kuantitatif, Penelitian Tindakan Kelas, Penelitian Pengembangan. UNP Press

8) Lukum, A., Studi, P., Kimia, P., Universitas, F., \& Gorontalo, N. (2019). Pendidikan 4 . 0 Di Era Generasi Z: Tantangan Dan Solusinya. Kompetensi berpikir. FKIP Universitas Mulawarman, 2(0), 2011-2013.

9) Nursyifa, A. (2019). Transformasi Pendidikan Ilmu Pengetahuan Sosial dalam Menghadapi Era Revolusi Industri 4.0. Jurnal Pendidikan Kewarganegaraan, 6(1), 51. https://doi.org/10.32493/jpkn.v6i1.y2019.p51-64

10) Mulyadi, N., Faisal, R., \& Diella, D. (2020). The relationship between self-regulated learning and learning motivation with metacognitive skills in biology subject. JPBI (Jurnal Pendidikan Biologi Indonesia), 6(3), 355-360.

11) Oktavian, R., \& Aldya, R. F. (2020). Efektivitas Pembelajaran Daring Terintegrasi di Era Pendidikan 4.0. Didaktis: Jurnal Pendidikan Dan Ilmu Pengetahuan, 20(2), 129-135. https://doi.org/10.30651/didaktis.v20i2.4763

12) Pramudita, I. F. E., Praherdhiono, H., \& Adi, E. P. (2021). Studi Keterampilan Abad 21 Mahasiswa Dalam Memilih Peminatan. JKTP: Jurnal Kajian Teknologi Pendidikan, 4(3), 251-259. https://doi.org/10.17977/um038v4i32021p251

13) Putri, A. R., \& Muzakki, M. A. (2019). Implemetasi Kahoot sebagai Media Pembelajaran Berbasis Digital Game Based Learning dalam Mengahadapi Era Revolusi Industri 4.0. Prosiding Seminar Nasional Universitas Muria Kudus, 1-7. http://pgsd.umk.ac.id/files/prosiding/2019/27__Aprilia_Riyana.pdf

14) Rahman, A., \& Nuryana, Z. (2019). Pendidikan Islam di Era Revolusi Industri 4.0. 34-0. https://doi.org/10.31219/osf.io/8xwp6

15) Razak A, Santosa T.A, Lufri. (2021). Meta-Analisis: Pengaruh Soal HOTS (Higher Order Thinking Skill) Terhadap Kemampuan Literasi Sains dan Lesson Study Siswa Pada Materi Ekologi dan Lingkungan Pada Masa Pandemi Covid-19. Bioedusiana, 6(1), 79-87. https://creativecommons.org/licenses/by-sa/4.0/

16) Sultoni, S., Gunawan, I., \& Argadinata, H. (2020). Dampak Pembelajaran Berkarakter Terhadap Penguatan Karakter Siswa Generasi Milenial. Jurnal Administrasi Dan Manajemen Pendidikan, 3(2019), 160-170. https://doi.org/10.17977/um027v3i22020p160

17) Trisna, B. N. (2019). Pendidikan 4.0: Perubahan Paradigma Dan Penguatan Kearifan Lokal Dalam Pembelajaran Matematika. Angewandte Chemie International Edition, 6(11), 951-952., 5(1), 5-24. 